Archive for

Organic Chemistry

Arkivoc 2020, part vii, 158-179

\title{
Transition metal-guanidine complexes as catalysts in organic reactions. Recent developments
}

\author{
Iratxe Barbolla, Nuria Sotomayor*, and Esther Lete*
}

Departamento de Química Orgánica II, Facultad de Ciencia y Tecnología, Universidad del País Vasco / Euskal Herriko Unibertsitatea UPV/EHU, Apdo. 644, 48080 Bilbao, Spain

Email: esther.lete@ehu.es

Dedicated to Professor Jan Bergman on the occasion of his 80th birthday

Received 06-05-2020

Accepted 07-17-2020

Published on line $07-28-2020$

\section{Abstract}

Guanidines have received great attention due to their application as superbasic proton sponges and organocatalysts, as well as excellent $\mathrm{N}$-donor ligands able to coordinate with different metals. The introduction of different substituents can modulate the basicity/nucleophilicity of the guanidines, their coordination ability, and thus, the electronic and steric properties of their metal complexes, regulating their catalytic activity. This review presents recent developments on guanidine-based ligand families [monoguanidine, bis(guanidine) and hybrid guanidine ligands], highlighting their potential in transition metalcatalyzed reactions.

acyclic, cyclic, bicyclic, bis(guanidines), hybrid guanidines

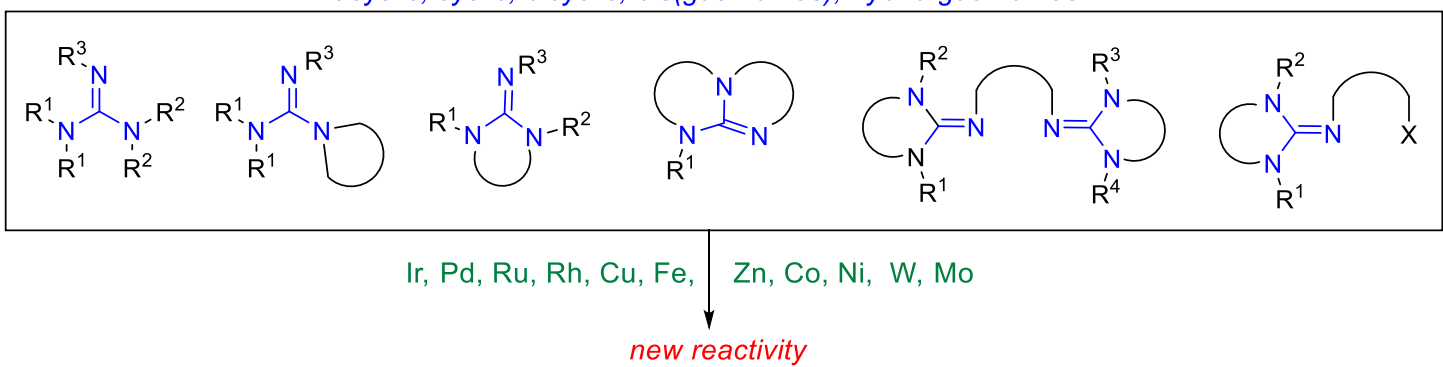

Keywords: Guanidine, metal-catalyzed reactions, asymmetric catalysis, transition metals 


\section{Table of Contents}

1. Introduction

2. Monoguanidines as Ligands in Metal-catalyzed Reactions

3. Bis- and Tetra(guanidines) as Ligands in Metal-catalyzed Reactions

4. Guanidine Hybrid Ligands in Metal-catalyzed Reactions

5. Other Applications

6. Conclusions

\section{Introduction}

The design of ideal catalysts able to promote efficiently a desired transformation is one of the primary goals in synthetic chemistry. In this context, guanidines ${ }^{1}$ have attracted much attention as, in addition to their wellknown applicability as superbasic proton sponges, ${ }^{2}$ they have shown remarkable applications as organocatalysts $^{3-5}$ and as ligands in transition metal coordination chemistry. ${ }^{6}$ In fact, guanidines have been found to be excellent $\mathrm{N}$-donor ligands due to the ability to delocalize a positive charge over the guanidine moiety, behavior that leads to strongly basic and highly nucleophilic compounds with an enhanced capability to coordinate to metal ions. Consequently, guanidine-type ligands have been employed for the preparation of highly active homogeneous catalysts in combination with transition metals, which may be able to promote different types of organic reactions. The introduction of different substituents can modulate the basicity/nucleophilicity of the guanidines, their coordination ability, and thus, the electronic and steric properties of their metal complexes, thus regulating their catalytic activity. In this way, it is possible to control the chemo-, regio-, and enantio-selectivities of a given reaction. Excellent recent reviews have been published covering the role of guanidine metal complexes in bioinorganic chemistry ${ }^{7}$ and on the use of guanidine ligands in metal catalyzed reactions. ${ }^{8}$ Herein we focus on recent key contributions on the application of the complexes of different types of guanidines [monoguanidines, bis(guanidines), hybrid guanidines] with transition metals as catalysts in chemical synthesis.

\section{Monoguanidines as Ligands in Metal-catalyzed Reactions}

The synthesis and chemistry of monoguanidines has been widely studied. A simple structure would be 1,1,3,3tetramethylguanidine 1 (TMG) (Figure 1), but also a variety of acyclic $\mathbf{2}$ (Barton's bases), cyclic 3 or bicyclic analogues 5-6, such as 1,3,4,6,7,8-hexahydro-2H-pyrimido[1,2-a]pyrimidine (hpp), also known as triazabicyclodecene (TBD) 6a have been widely studied. For example, as part of our program to develop new synthetic methods for heterocyclic systems, ${ }^{9-12}$ we have prepared several cyclic guanidines, 2-aminoimidazoles of general structure $4,{ }^{13}$ whose framework can be found in biologically active natural products. ${ }^{14}$ 


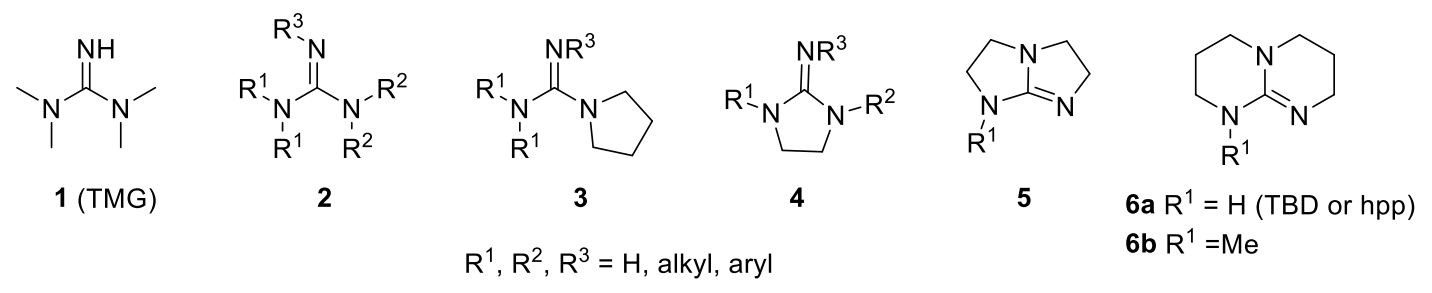

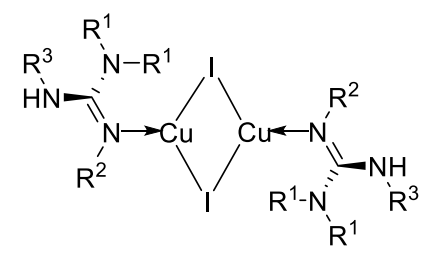

7

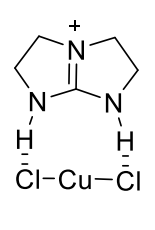

8

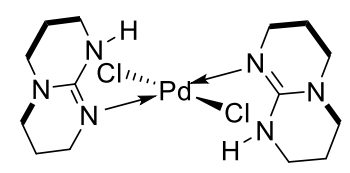

9

Figure 1. Acyclic, cyclic/bicyclic monoguandines and their complexes with transition metals.

Monoguanidines can present various coordination modes with the metal center, so their complexes with transition metals (e.g. copper or palladium) can present different geometries and properties (Figure 1, complexes 7-9). Nevertheless, the use of guanidine metal complexes as catalysts in organic synthesis is limited to a few examples until now. Among them palladium-catalyzed cross-coupling reactions (Heck ${ }^{15,16}$ and Suzuki $^{17,18}$ reactions) or ruthenium-catalyzed isomerization of allylic alcohols ${ }^{19}$ are excellent examples of monoguanidine-transition metal complexes-catalyzed reactions, as has been recently covered in a recent review. ${ }^{8}$ Besides, tetra-substituted guanidinate anions, formed by deprotonation of neutral guanidine with a free $\mathrm{N}-\mathrm{H}$, are bidentate ligands with stronger coordination ability than neutral guanidines. Thus, guanidinate complexes of the platinum group metals have also interesting applications in catalysis. ${ }^{20}$ Another interesting cross coupling reaction is the selective cross-dimerization between trialkylsilylacetylenes $\mathbf{1 0}$ and terminal alkylor arylacetylenes $\mathbf{1 1}$ using iridium(I)-guanidinate complex $\mathbf{1 3}$ as catalyst. It is noteworthy that when using alkyl acetylenes 11 the $E / Z$ selectivity of the obtained enynes 12 could be controlled by changing phosphine (Scheme 1). ${ }^{21}$
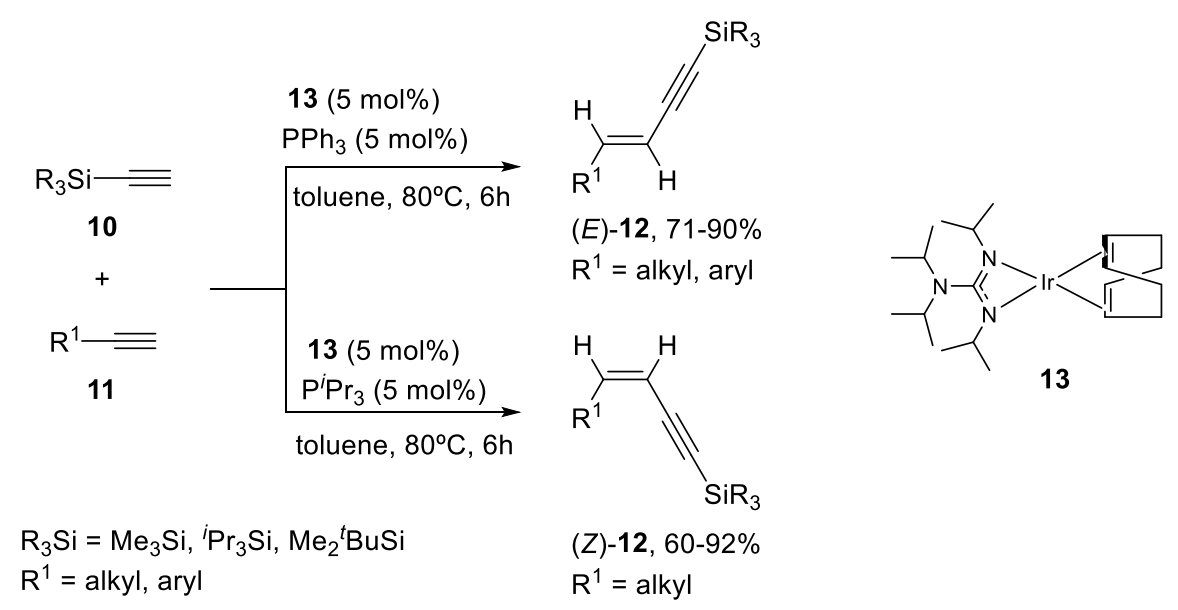

Scheme 1. Cross-dimerization between silylacetylenes and acetylenes catalyzed by an Ir(I) complex.

In a related example, a cobalt-catalyzed trimerization of internal alkynes to yield polysubstituted arenes has been successfully achieved using a cobalt complex of 1,2,3-tris(2,6-diisopropylphenyl)guanidine, also using low 
catalyst loadings (4 mol\%). ${ }^{22}$ On the other hand, dinuclear palladium catalysts with potential for metal-metal redox cooperation have also been evaluated for some important redox transformations. Thus, Ritter ${ }^{23}$ has reported a chemo- and regioselective $\alpha$-hydroxylation reaction of carbonyl compounds with molecular oxygen or air as oxidant, using paddlewheel dinuclear Pd(II) complex 16 with bicyclic guanidine triazabicyclodecene (TBD) 6a (Scheme 2). ${ }^{24}$ This complex acts in a similar way as oxygenase enzymes transferring oxygen to the substrate. ${ }^{25}$ For example, $\alpha$-methyl- $\beta$-tetralone $14 \mathbf{k}$ was transformed into the corresponding $\alpha$-hydroxy- $\alpha$ methyl- $\beta$-tetralone 15k under one atmosphere of $\mathrm{O}_{2}$ using the complex $16(5 \mathrm{~mol} \%)$ in a good yield. The procedure has a wide scope and it has been applied to the regioselective synthesis of a variety of tertiary alcohols 15a-I. The hydroxylation reaction always takes place on the more substituted carbon atom, even in substrates with more acidic methylene protons, such as $\mathbf{1 4} \mathbf{i}-\mathbf{j}$.

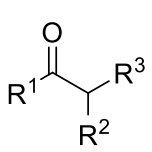

14

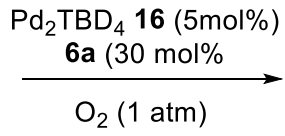

$\mathrm{THF}, 0-6^{\circ} \mathrm{C}, 12-24 \mathrm{~h}$

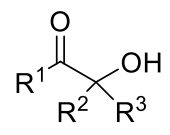

$15,60-97 \%$

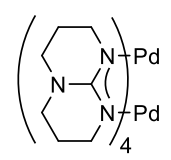

$\mathrm{Pd}_{2} \mathrm{TBD}_{4} 16$<smiles>[R]C(=O)C([R])([R])O</smiles>

15a, $\mathrm{R}^{1}=\mathrm{Me}, \mathrm{R}^{2}=\mathrm{CPr}, \mathrm{R}^{3}=\mathrm{CO}_{2} \mathrm{Et}, 94 \%$

$15 b, R^{1}=R^{2}=P h, R^{3}=M e, 99 \%$

15c, $R^{1}=P h, R^{2}=R^{3}=M e, 80 \%$

$15 d, R^{1}=O M e, R^{2}=R^{3}=P h, 77 \%$

15e, $R^{1}=P h, R^{2} R^{3}=$ Cyp, $60 \%$

15f, $R^{1}=N$-Bocindol-2-yl, $R^{2}=M e, R^{3}=$ COMe, $70 \%$

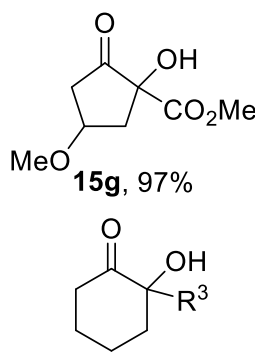

15i, $\mathrm{R}^{3}=\mathrm{Ph}, 70 \%$ $15 \mathrm{j}, \mathrm{R}^{3}=\mathrm{Bn}, 68 \%$

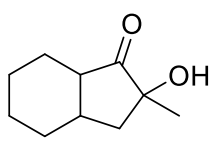

$15 \mathrm{~h}, 88 \%$

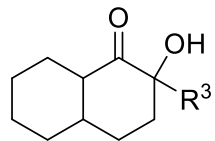

15k, $\mathrm{R}^{3}=\mathrm{COMe}, 96 \%$

15I, $R^{3}=\mathrm{Me}, 91 \%$

Scheme 2. $\alpha$-Hydroxylation of carbonyl compounds catalyzed by a dinuclear Pd(II) complex.

The potential of monoguanidines in metal-mediated reactions is also illustrated in the transition metalcatalyzed Huisgen 1,3-dipolar cycloaddition between azides and alkynes (AAC). ${ }^{26}$ Half-sandwich electrondeficient $N, N^{\prime}, N^{\prime \prime}$-triarylguanidinatoruthenium(II) complexes 20 were prepared by reaction of the corresponding triaryl guanidine $\left[(\mathrm{ArNH})_{2} \mathrm{C}=\mathrm{NAr}\right]$ and $\left[\left(\eta^{6}-p \text {-cymene }\right) \mathrm{Ru}(\mu-\mathrm{Cl}) \mathrm{Cl}\right]_{2}$. These complexes were able to catalyze the $\mathrm{Cu}(\mathrm{I})$ catalyzed click reaction of an aryl azide 17 and phenylacetylene 18 affording a $2.7: 1$ mixture of 1,4- and 1,5-disubstituted triazoles 19a/19b, from which the major isomer 19a could be isolated in a $62 \%$ yield. The presence of AgOAc was required for the reaction to take place (Scheme 3). ${ }^{27}$ 


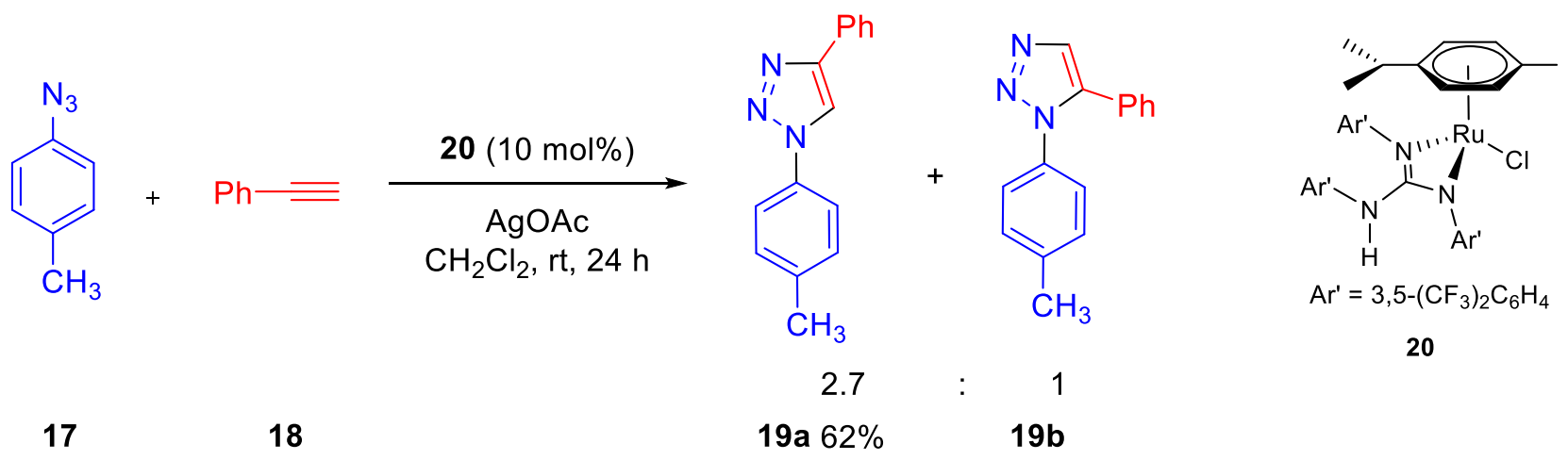

Scheme 3. Azide-alkyne 1,3-dipolar cycloaddition catalyzed by half sandwich Ru(II) complexes.

Guanidine-functionalized magnetic nanoparticles anchored to $\mathrm{Fe}(\mathrm{II})$ - or $\mathrm{Cu}(\mathrm{II})$-phthalocyanine complexes $\mathbf{2 5}$ have shown to be efficient catalysts in another click reaction, the condensation of acetophenone $\mathbf{2 1}$, aromatic aldehydes $\mathbf{2 2}$ and nitriles $\mathbf{2 3}$ to give the corresponding $\beta$-ketoamides $\mathbf{2 4}$ (Scheme 4 ). ${ }^{28}$ The procedure requires low loading of the catalysts, which can be reused at least six times without losing their catalytic activity.

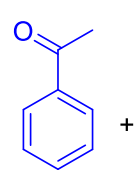

21

$\mathrm{R}^{1}=\mathrm{Me}, \mathrm{Bn}$

$\mathrm{R}^{2}=\mathrm{F}, \mathrm{Cl}, \mathrm{Br}, \mathrm{MeO}, \mathrm{NO}_{2}$

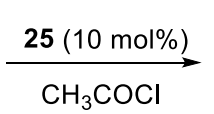

22

$\mathrm{CH}_{3} \mathrm{COCl}$

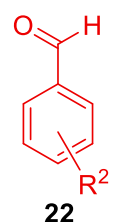

.

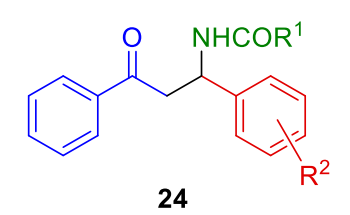

24

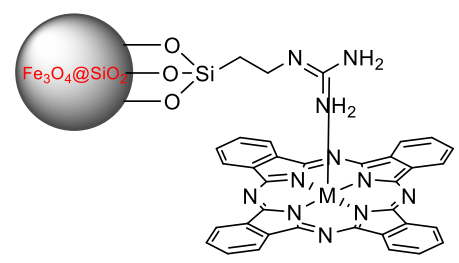

25a, $\mathrm{M}=\mathrm{Cu}$ 25b, $M=F e$

Scheme 4. Click reaction of acetophenone, aromatic aldehydes and nitriles catalyzed by guanidinefunctionalized magnetic nanoparticles.

In the context of polymer chemistry, copper complexes with chelating $\mathrm{N}$-donor ligands are the most important atom transfer radical polymerization (ATRP) catalysts, ${ }^{29-31}$ and many examples of radical polymerization reactions using different types of monoguanidines as ligands for $\mathrm{Cu}(\mathrm{I})$ have been reported. ${ }^{32}$ Recently, the simple guanidine $\mathbf{1}$ (TMG) has been used for the ATRP of methyl methacrylate (MMA) 26 in the presence of $\mathrm{Cu}(0)$ wire and $\mathrm{CuBr}_{2}$ using ethyl 2-bromo-2-phenylacetate as initiator (Scheme 5). ${ }^{33}$ Here TMG plays a dual function, ligand and reducing agent. Polymethymethacrylate (PMMA) 27 was synthesized with molecular weight up to 100.000 and low polydispersity ( $\mathrm{Mw} / \mathrm{Mn}<1.3)$, using low concentrations of $\mathrm{CuBr}_{2}(100$ $\mathrm{ppm}$ ). The procedure could be successfully applied to different methacrylic monomers.

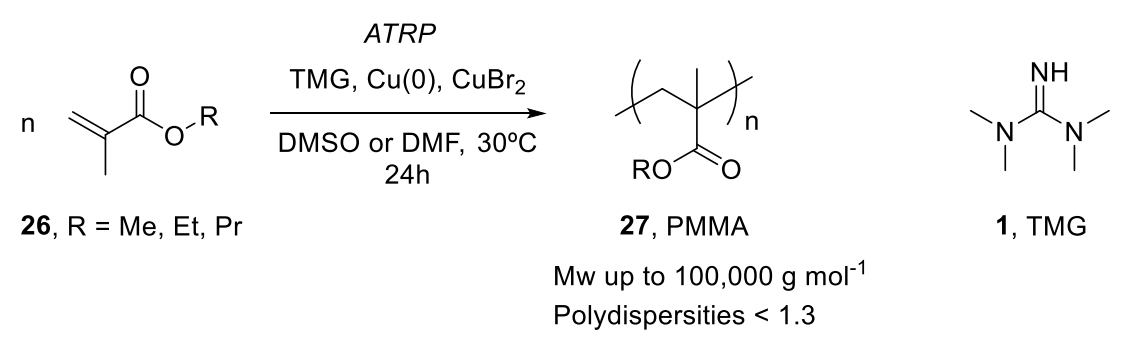

Scheme 5. ATR polymerization of methacrylates catalyzed by a $\mathrm{Cu}(\mathrm{I})$ complex. 
As shown, monoguanidines are well-known and versatile ligands. However, little is known about the suitability of chiral metal complexes of guanidine as asymmetric catalysts. Recently, the enantioselective alkynylation of racemic cyclic allylic bromides $\mathbf{2 8}$ has been accomplished with terminal alkynes 29 using a chiral guanidinium complex derived from $\mathbf{3 1}$ as catalyst under biphasic conditions. The authors proposed that a copper complex bearing a single guanidine ligand should be involved on the enantio-determining step, based on an observed linear correlation between the enantiopurity of the catalyst and reaction product. The alkynylation of the cyclic allylic bromides 28 underwent an anti- $S_{N} 2^{\prime}$ pathway catalyzed by a nucleophilic cuprate species, as demonstrated both experimental and computationally (Scheme 6a). ${ }^{34}$ Additionally, the same chiral guanidine- $\mathrm{Cu}(\mathrm{I})$ complex was efficiently employed as catalyst in the $\mathrm{S}_{\mathrm{N}} 2^{\prime}$ borylation process of racemic cyclic allylic bromides 32 with bis(pinocalato)diboron 33, which afforded enantioenriched secondary and tertiary cyclic allyl boronates $\mathbf{3 4}$ (Scheme $6 \mathrm{~b}$ ). ${ }^{35}$

a)

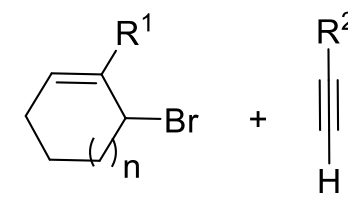

28

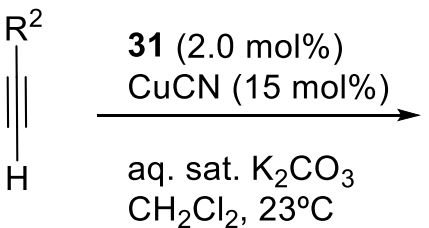

29

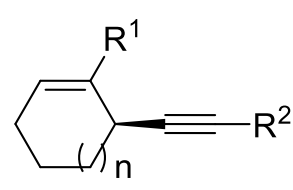

$30,52-95 \%$ $81-96 \%$ ee

$\mathrm{n}=1,2,3 ; \mathrm{R}^{1}=\mathrm{H}, \mathrm{Me}, \mathrm{Ph} ; \mathrm{R}^{2}=$ aryl, benzyl, alkyl, TMS

b)

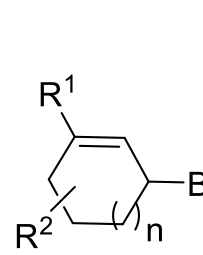

32

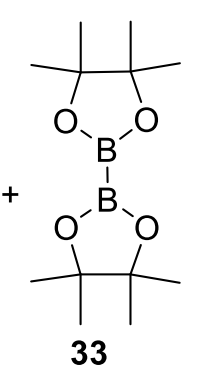

$\mathrm{n}=1,3 ; \mathrm{R}^{1}=\mathrm{H}$, alkyl, benzyl; $\mathrm{R}^{2}=\mathrm{H}, \mathrm{Me}$
$31(1.5 \mathrm{~mol} \%)$

$\mathrm{Cu}\left(\mathrm{NO}_{3}\right)_{2} \cdot 3 \mathrm{H}_{2} \mathrm{O}(1 \mathrm{~mol} \%)$

aq. sat. $\mathrm{K}_{2} \mathrm{CO}_{3}$ hexane, $23^{\circ} \mathrm{C}$

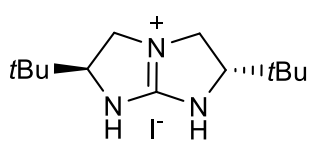

31

Scheme 6. Enantioselective alkynylation and borylation of racemic allylic bromides catalyzed by a chiral Cu(I)guanidine complex.

\section{Bis- and Tetra(guanidines) as Ligands in Metal-catalyzed Reactions}

Large libraries of bis(guanidines) have been generated using modular synthesis as a strategy to introduce different spacers between the two guanidine units. In this context, Harmjanz and coworkers ${ }^{36}$ reported the preparation of 1,3-bis $\left(N, N, N^{\prime}, N^{\prime}\right.$-tetramethylguanidino)propane 35 (TMG $\left.2 \mathrm{p}\right)$, which represented the first bidentate peralkylated guanidine ligand that consisted of two tetramethylguanidine units bridged with an alkyl linker. It was thought that the steric demands of the two tetramethylguanidine residues, the flexible trimethylene bridge backbone and the strong basicity of guanidine moieties could make $\mathrm{TMG}_{2} \mathrm{p}$ ligand a versatile tool in metal complex chemistry. Therefore, the complexation chemistry of the ligand was examined towards the preparation of $\left[\mathrm{TMG}_{2} \mathrm{p} \mathrm{MX_{n }}\right.$ ] type coordination compounds 39 with copper and iron salts in different oxidation states through the diimine nitrogens of the ligand (Figure 2). Among the wide variety of 
peralkylguanidine ligands with different bridging moieties, the use of 1,2-bis(tetramethylguanidino)benzene $36\left(\mathrm{TMG}_{2} \mathrm{p}\right)$ and 2,6-bis(tetramethylguanidino)methylpyridine $\mathbf{3 7}$ ( $\mathrm{TMG}_{2} \mathrm{py}$ ) for the synthesis of late- and posttransition-metal complexes, such as platinum, zinc or magnesium, (Figure 2) has been widely studied. ${ }^{37,38}$ More recently, chiral $\mathbf{Z n}(\mathrm{II})$ chloride bis(guanidine) complexes $\mathbf{4 0}$ derived from both enantiomeric forms of TMG substituted trans-1,2-diaminocyclohexane derivatives 38 have been reported(Figure 2). ${ }^{39}$

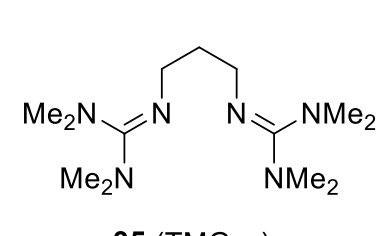

$35\left(\mathrm{TMG}_{2} \mathrm{p}\right)$

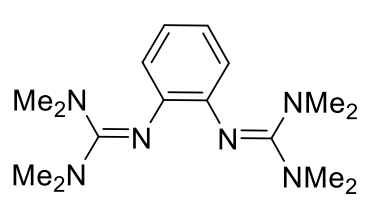

$36\left(\mathrm{TMG}_{2} \mathrm{~b}\right)$

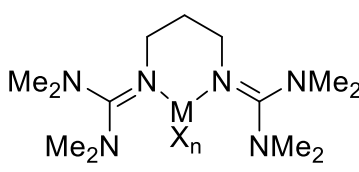

$39\left[\mathrm{TMG}_{2} \mathrm{pMX}_{\mathrm{n}}\right]$ $\mathrm{M}=\mathrm{Cu}(\mathrm{I}), \mathrm{Cu}(\mathrm{II}), \mathrm{Fe}(\mathrm{II})$ $X=C l, I$

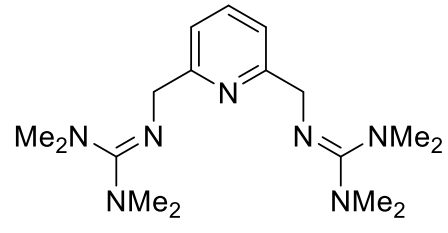

$37\left(\mathrm{TMG}_{2} \mathrm{py}\right)$

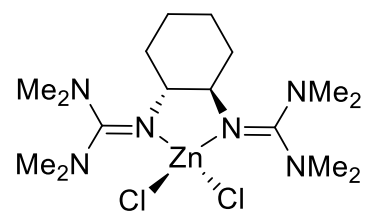

$40\left[\left\{(R, R)-\mathrm{TMG}_{2}(1,2)\right\} \mathrm{chZnCl}_{2}\right]$

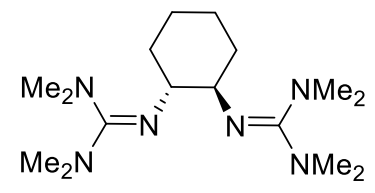

$38\left[(R, R)-\mathrm{TMG}_{2}(1,2) \mathrm{ch}\right]$

Figure 2. Bis(guanidines) and their complexes with transition-metals.

On the other hand, Sundermeyer and coworkers $^{40}$ reported on the synthesis of 1,8bis(tetramethylguanidino)naphthalene $\left(\mathrm{TMG}_{2} \mathrm{n}\right)$, an extremely basic guanidine derivative and kinetically active proton sponge. In fact, it presents two basic nitrogen centers in the molecule with the adequate orientation to uptake a proton, which constitutes the general backbone of all proton sponges. Besides, 1,8- TMG ${ }_{2} \mathrm{n}$ exhibits a rich coordination chemistry through the lone pairs at the imine-nitrogen atoms. Thus, the first transition metal complexes of $\mathrm{TMG}_{2} \mathrm{n}$ with palladium and platinum salts were prepared in 2008 by Himmel. ${ }^{41}$ Additionally, preliminary catalytic studies revealed that Heck reaction between styrene and phenyl iodide could be efficiently catalyzed by $\left[\left(\mathrm{TMG}_{2} \mathrm{n}\right) \mathrm{PdCl}_{2}\right]$ complex, yielding almost quantitatively trans-stilbene using very low catalytic loading (0.2 mol\%). Furthermore, platinum complexes with $\mathrm{TMG}_{2} \mathrm{n}$, were found to be highly active catalyst for hydrosilylation reaction between $\mathrm{Et}_{3} \mathrm{SiH}$ and trimethyl(vinyl)silane. ${ }^{41}$

More recently, oxidation reactions of organic compounds with dioxygen using molecular copper complexes have also been investigated. In particular, hydroxylation reactions of aliphatic substrates that mimic the activity of enzymes as peptidylglycine monooxygenase (PHM), whose activity depends the cooperative effect between two copper atoms. Thus, it has been shown that metal cooperativity in nuclear copperbis(guanidine) complexes allowed aliphatic $\mathrm{C}-\mathrm{H}$ bond cleavage by oxygen. To demonstrate the use of these cooperative effects in organic reactions, this strategy has been applied to the aldol reaction of acetone $\mathbf{4 1}$ to give 4-hydroxy-4-methylpentan-2-one 42 catalyzed by a dinuclear copper complex 43 (Scheme 7). DFT calculations suggest that the reaction takes place via a Proton-Coupled Electron-Transfer (PCET) process induced by in the cooperative effects between the two copper atoms of the complex. Only one of the copper atom can bind and activate dioxygen, while the other one stabilizes the product of PCET by copper- ligand charge transfer. ${ }^{42}$ 
2

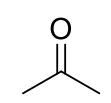

41

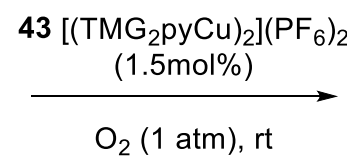

$\mathrm{O}_{2}$ (1 atm), rt

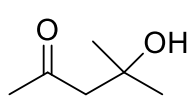

42

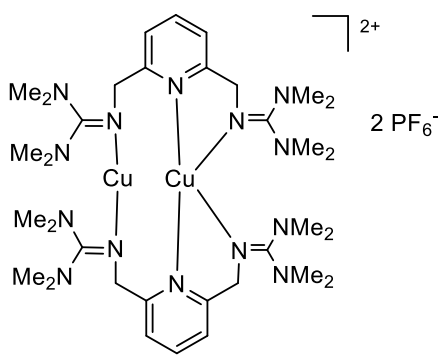

$43\left[\left(\mathrm{TMG}_{2} \mathrm{pyCu}\right)_{2}\right]\left(\mathrm{PF}_{6}\right)_{2}$

Scheme 7. Aldol reaction catalyzed by a dinuclear $\mathrm{Cu}(\mathrm{I})$ complex.

A related class of widely studied guanidine-type ligands is represented by bis(imidazolin-2-imine) ligands, which exhibit pronounced electron-donating capacity due to the particularly effectiveness of the imidazolium ring to stabilize a positive charge ${ }^{43}$ thus showing great tendency to stabilize catalytically active complexes. The coordination chemistry of the bis(imidazolin-2-imine) ligands depends on the steric and electronic properties of the ligands, which can be easily changed by introducing different 2-iminoimidazolines or by using different bridging moieties. Therefore, 1,2-bis(imidazolin-2-imino)ethane ligands 44a-b have found widespread use in organometallic and coordination chemistry (Figure 3). Due to the strong basic nature of the novel bis(imidazolin-2-imine) ligands, very stable half-sandwich 16-electron pentamethylcyclopentadienylruthenium(II) complexes $\mathbf{4 5}$ have been formed. Although they are inert towards hard, $\pi$-basic ligands, they have showed high reactivity towards soft $\sigma$-donor/ $\pi$-acceptor ligands such as $\mathrm{CO}$ and isocyanides. Consequently, complexes $\mathbf{4 5}$ have resulted highly reactive in the activation of small molecules, such as $\mathrm{N}_{2}$ and $\mathrm{H}_{2}$, so they are also promising candidates for catalytic applications. ${ }^{44}$ Similar donor properties were found in analogous 16-electron cycloheptatrienyl-molybdenum(0) half-sandwich complexes of ethylene-bridged bis(imidazolin-2-imine) ligands. ${ }^{45}$

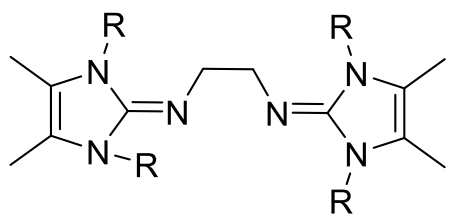

44a, $R=M e$ 44b, $\mathrm{R}=i \mathrm{Pr}$

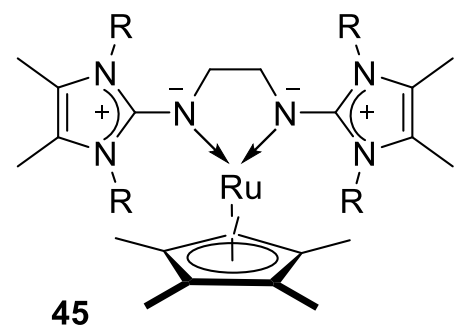

45<smiles></smiles>

46

Figure 3. 1,2-Bis(imidazolin-2-imino)ethane ligands and their complexes with transition-metals.

In contrast, copper(I) halide complexes $\mathbf{4 6}$ are easily oxidized, which makes them useful for atom transfer radical polymerization (ATRP). Thus, $46\left(\mathrm{R}={ }^{i} \mathrm{Pr}\right.$ ) complex showed a good catalytic activity in the ATRP polymerization of styrene 47, using 1-phenylethyl chloride as an initiator in toluene under reflux (Scheme 8). Other examples of radical polymerization reactions using different types of bis(guanidines) ${ }^{46}$ and tris(guanidines) ${ }^{47}$ as ligands for $\mathrm{Cu}(\mathrm{I})$ have also been described. 
n<smiles>C=Cc1ccccc1</smiles>

47

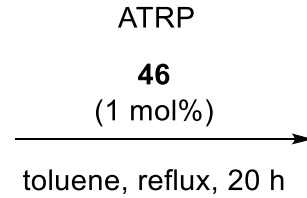

toluene, reflux, $20 \mathrm{~h}$

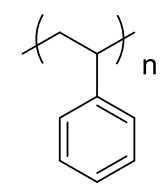

48

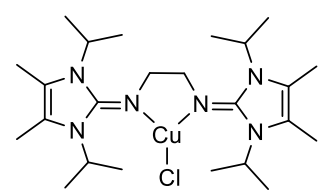

46

$\mathrm{Mn}<30,000 \mathrm{~g} \mathrm{~mol}^{-1}$

Polydispersity1.14-1.59)

Scheme 8. ATR polymerization of styrene catalyzed by $\mathrm{Cu}(\mathrm{I})$ complexes.

Besides, Tamm and coworkers ${ }^{48}$ described a pyridine-bridged bis(imidazolin-2-imine) pincer ligand 49a $(R=$ 'Pr) capable of forming highly reactive copper(I) complexes that allowed effective aerobic $\mathrm{CO}_{2}$ fixation, $\mathrm{C}-\mathrm{Cl}$ bond activation and $\mathrm{Cu}(\mathrm{l})$ disproportionation. The same group extended the study of the complexes of pincer ligand $49 \mathrm{~b}\left(\mathrm{R}={ }^{t} \mathrm{Bu}\right)$ with "earlier" first row transition metals (manganese, iron, cobalt and nickel) $50^{49}$ and to different lanthanide metals (yttrium, erbium and lutetium) 51, with a variety of geometries (tetrahedral, square planar, square pyramidal) (Figure 4$).^{50}$

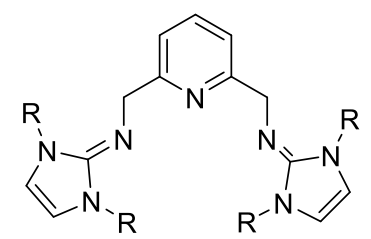

49a, $\mathrm{R}={ }^{i} \mathrm{Pr}$

49b, $\mathrm{R}={ }^{t} \mathrm{Bu}$

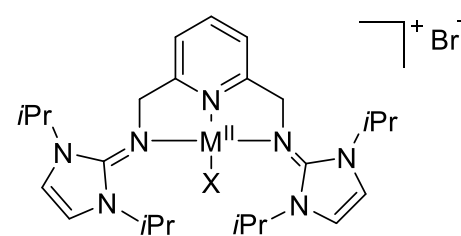

50

$\mathrm{M}=\mathrm{Ni}, \mathrm{Mn}, \mathrm{Fe}$ $\mathrm{X}=\mathrm{Br}$, OTf

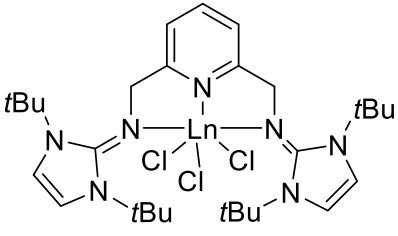

51

$\mathrm{Ln}=\mathrm{Y}, \mathrm{Er}, \mathrm{Lu}$

Figure 4. Pyridine bis(imidazolin-2-imines) pincer ligands and their complexes with transition-metals and lanthanides.

N,N'-(1,2-phenylene)bis(1,3-dimethylimidazolidin-2-imine) ligands $\mathbf{5 2}$ have been found to be powerful hydrogen acceptors. In fact, the bidentate type hydrogen bonding interaction between two guanidinyl functions of the ligand and the $\mathrm{OH}$ group of a variety of hydrogen donor aromatics led to successful formation of the corresponding complexes 53 (Figure 5). ${ }^{51}$ Furthermore, the coordination to different metal ions has also been studied. Thus, the preparation of mononuclear $\mathrm{Zn}(\mathrm{II}), \mathrm{Co}(\mathrm{II})$ and $\mathrm{Ni}(\mathrm{II})$ complexes $\mathbf{5 4}$ has been achieved (Figure 5) from which $\mathrm{CoCl}_{2}$-guanidine complex resulted suitable for paramagnetic NMR spectroscopic studies, such as ${ }^{1} J_{C, H}$ correlation experiments. ${ }^{52,53}$

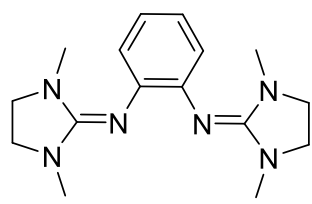

52

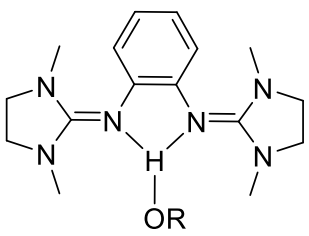

53

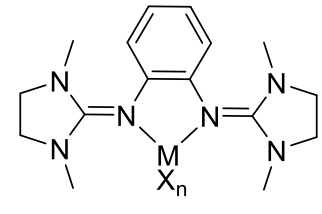

54

$\mathrm{M}=\mathrm{Zn}(\mathrm{II}), \mathrm{Co}(\mathrm{II}), \mathrm{Ni}(\mathrm{II})$ $\mathrm{X}=\mathrm{Et}, \mathrm{Cl}, \mathrm{Br}$

Figure 5. $N, N^{\prime}$-(1,2-phenylene)bis(1,3-dimethylimidazolidin-2-imine) ligands and their complexes. 
Regarding the use of bis(guanidine) ligands in asymmetric catalysis, a major breakthrough has been accomplished by Tan and coworkers, which implies the use of a chiral cation in combination with inorganic anionic metal salts to promote oxidation reactions (Scheme 9). Chiral dicationic bis(guanidinium) catalysts, such as 55, have been developed for this purpose. Chiral induction is accomplished by ion pairing interaction between the chiral cation and a reactive metal anionic species. Thus, the oxidation of alkenes $\mathbf{5 6}$ with potassium permanganate in the presence of the chiral dicationic ligand 55a gives hydroxyketones $\mathbf{5 7}$ with almost perfect control of the enantioselectivity (Scheme 9 a). ${ }^{54}$ The authors proposed that the potassium permanganate would coordinate dynamically to both faces of the alkene. However, the chiral catalyst accelerates the oxidation reaction by the selective formation of an intimate ion pair with the resulting enolate only in the matched transition state.

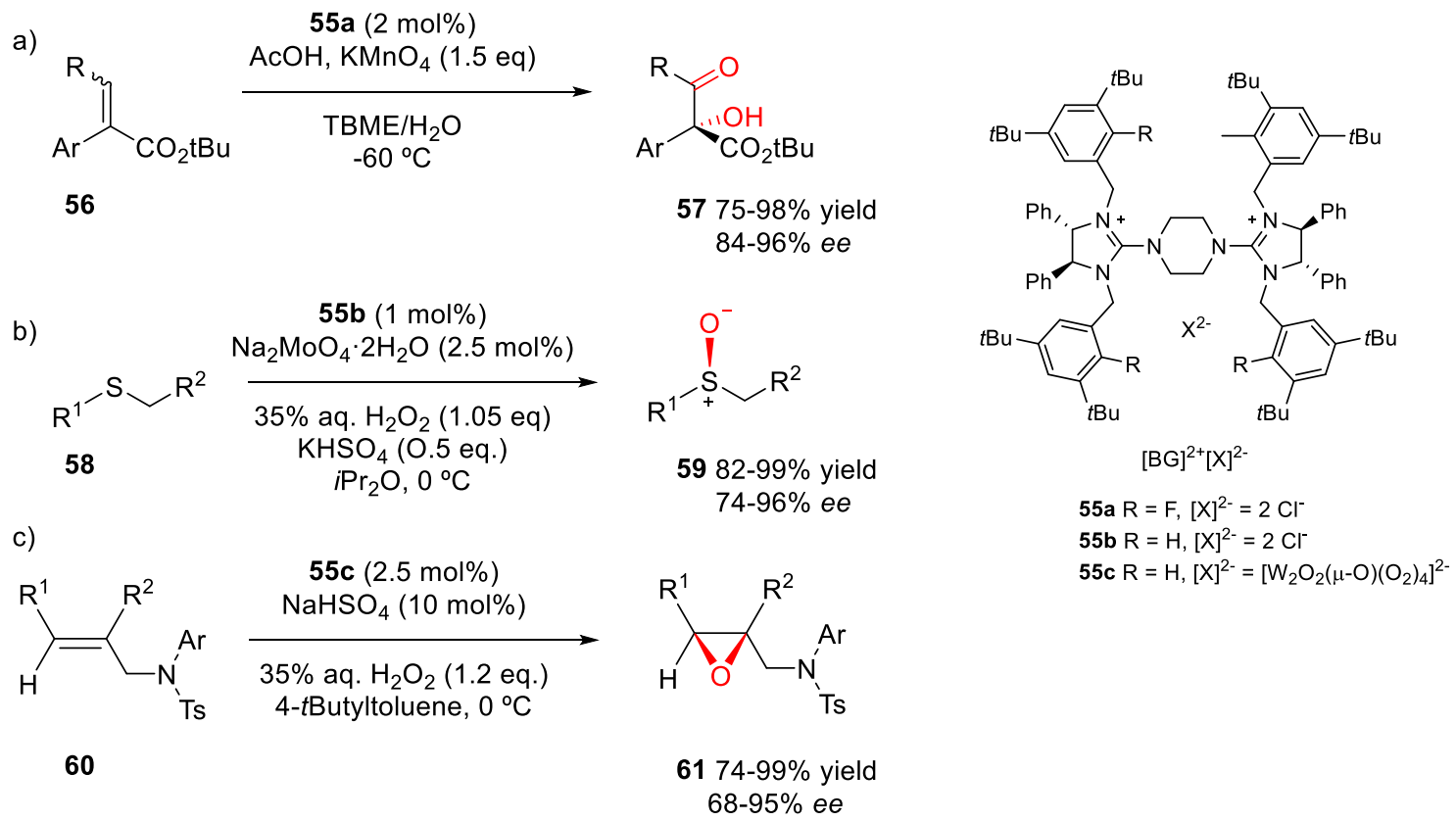

Scheme 9. Enantioselective oxidation reactions catalyzed by chiral bis(guanidinium) complexes.

In a further application, they have also shown the applicability of cationic bis(guanidinium) 55b in combination with $\mathrm{Na}_{2} \mathrm{Mo}_{4}$ and using aqueous $\mathrm{H}_{2} \mathrm{O}_{2}$ as the terminal oxidant in the enantioselective oxidation of a wide variety of sulfides to sulfoxides (Scheme $9 \mathrm{~b}$ ). ${ }^{55}$ In this case, the active catalytic species would be a dinuclear oxodiperoxomolybdosulfate $[\mathrm{BG}]^{2+}\left[\left(\mu_{2}-\mathrm{SO}_{4}\right)\left\{\mathrm{Mo}_{2} \mathrm{O}_{2}\left(\mu_{2}-\mathrm{O}_{2}\right)_{2}\left(\mathrm{O}_{2}\right)_{2}\right\}\right]^{2-}$ ion pair formed in situ from $\mathbf{5 5 b}$. This reactive catalytic species is stable and could be isolated and characterized by X-Ray crystallography, showing that the anionic metallic species is embedded in the chiral cavity of the guanidinium cation. The methodology has been applied for a gram-scale synthesis of armodafinil using only a 0.25 mol $\%$ of the guanidinium catalyst. More recently, catalyst 55c, that contains the chiral cationic guanidinium and a tetraperoxyditungstate anion, has been applied for the highly selective epoxidation of allylic amines 60 , using aqueous hydrogen peroxide as the terminal oxidant under phase transfer conditions. The active species has also been studied by X-Ray diffraction and by IR and Raman spectroscopies, and the method applied for the synthesis of (-)-venlafaxine. ${ }^{56}$

Guanidine ligands have also been applied in visible light photoredox catalysis, an area that has emerged as an excellent tool in synthetic organic chemistry, mainly using photocatalysts based on ruthenium (II) and iridium (III) complexes. However, over the last years, earth-abundant metal complexes have begun to play an 
important role in photoredox reactions. ${ }^{57}$ In this regard, Zysman-Colman has recently reported the first examples of photoactive cobalt(III) complexes with bicyclic guanidine ligands $\mathbf{6 2}$ for the photocatalytic trifluoromethylation of polycyclic aromatic hydrocarbons 63 (Scheme 10). ${ }^{58}$ This highly regioselective reaction takes place at room temperature and pressure under nitrogen atmosphere using trifluoromethanesulfonyl chloride.

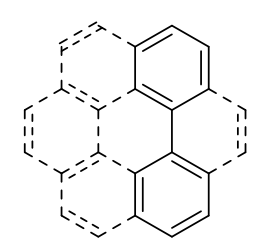

63

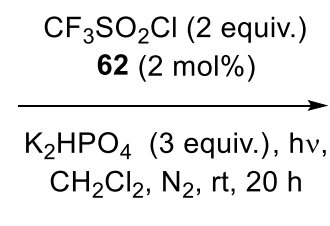

$\mathrm{HPO}_{4}$ (3 equiv.), h
$\mathrm{CH}_{2} \mathrm{Cl}_{2}, \mathrm{~N}_{2}, \mathrm{rt}, 20 \mathrm{~h}$

(

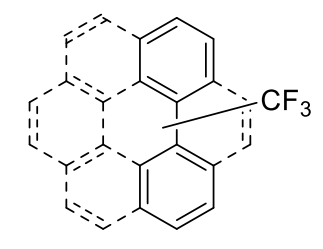

$6441-59 \%$

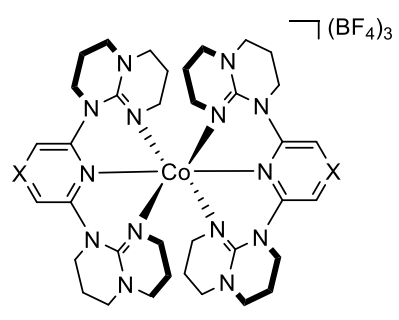

62a, $\left.\mathrm{X}=\mathrm{CH},\left[\mathrm{Co}(\text { dgpy })_{2}\right]\left(\mathrm{BF}_{4}\right)_{3}\right]$ 62b, $\left.\mathrm{X}=\mathrm{N},\left[\mathrm{Co}(\mathrm{dgpz})_{2}\right]\left(\mathrm{BF}_{4}\right)_{3}\right]$

Scheme 10. Photocatalytic trifluoromethylation of polycyclic aromatic hydrocarbons catalyzed by Co(III) complexes.

The development of a structurally related class of potentially strong electron donors and $\mathrm{N}$-bases by introduction of at least four guanidine groups on aromatic systems has also been reported. This way, binuclear metal complexes would be formed through the coordination of the tetraguanidine ligand to two metal centers. For example, Himmel found that 1,2,4,5-tetrakis(tetramethylguanidino)benzene (TTMGb) ${ }^{59}$ was found to be a good chelating ligand for the construction of binuclear late transition-metal complexes with zinc, copper and platinum. ${ }^{60,61}$ More recently, it was demonstrated that copper(I) catalysts bearing the redox-active guanidine ligand TTMGb 65 [(CuBr2(TTMGb)] could also efficiently promote the oxidative C-C homo- and cross-coupling reactions of phenols 66 and 67 (Scheme 11). ${ }^{62}$ Structurally related ligands containing a tetraguanidine unit have also been described to form complexes with $\mathrm{Co}(\mathrm{II}), \mathrm{Ni}(\mathrm{II}), \mathrm{Au}(\mathrm{I})$ and mainly $\mathrm{Cu}(\mathrm{I}) .{ }^{63-66}$

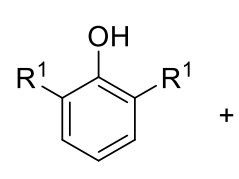

66

$\mathrm{R}^{1}=\mathrm{Me}, \mathrm{Bu}, \mathrm{OMe}$

$\mathrm{R}^{2}=\mathrm{R}^{3}=\mathrm{H}$, OMe;

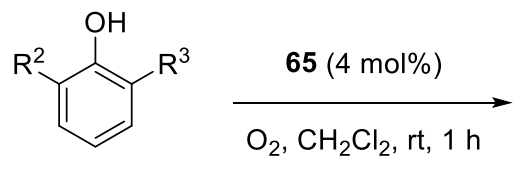

67

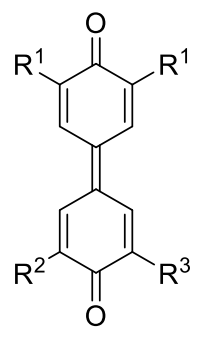

68, $45-97 \%$

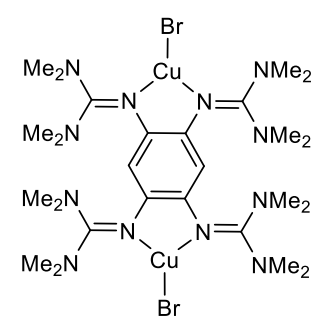

$65\left[(\mathrm{TTMGb})(\mathrm{CuBr})_{2}\right]$

Scheme 11. Aerobic phenol homo- and cross-coupling reactions catalyzed by $\mathrm{Cu}(\mathrm{I})$ complexes.

Finally, one application of guanidine modified metal-organic frameworks (MOFs) in catalysis is described. MOFs are porous hybrid materials assembled by metal ions or clusters connected with organic functional groups (carboxylates, amines, etc.) that form infinite one-, two- or three-dimensional frameworks. In particular, the chromium terephthalate metal-organic framework, MIL-101 (MIL, Matérial Institut Lavoisier) is formed by trimeric chromium(III) octahedral clusters interconnected by 1,4-benzenedicarboxylates, which can be further functionalized. ${ }^{67}$ Thus, iron-decorated, bis(guanidine) functionalized metal-organic frameworks (MOFs) have been developed as a non-heme iron-based enzyme mimic system for catalytic oxidation of 
organic substrates. A modified MOF (MIL-101(Cr)-bis(guanidine)-Fe has been used as catalyst in different oxidation reactions: (1) epoxidation of alkenes, (2) oxidation of primary or secondary alcohols to aldehydes or ketenes, respectively, and (3) oxidation of alkyl arenes to the corresponding ketones. All the reactions were carried out at room temperature using $\mathrm{H}_{2} \mathrm{O}_{2}$ as an oxidant. ${ }^{68}$

\section{Guanidine Hybrid Ligands in Metal-catalyzed Reactions}

So far, the selected examples of guanidine-type ligands show identical donor strengths and substituents with exactly the same steric demand. However, the construction of hybrid guanidine ligands by combination of a very strong $\mathrm{N}$-donor guanidine moiety with a different weak donor function is also possible. This way, the ligand enables the creation of a catalytic system with a strong complexation of the transition metal and a flexible coordination sphere.

In this context, Herres-Pawlis and coworkers considered that the combination of the excellent donor properties of guanidines with additional coordination space for pre-coordination of substrates could improve the catalytic activity of the existing guanidine-based zinc complexes in lactide polymerization reaction. ${ }^{69}$ Thus, they modified the symmetric bis(guanidine) ligands by substituting one bulky guanidine moiety by a pyridine or quinoline unit, leading to guanidine-pyridine and guanidine-quinoline hybrid ligands 69-72 shown in Figure 6. Copper complexes of the guanidine-pyridine hybrid ligand $\mathbf{7 1}$ (Figure 6) were shown to mediate in the solvent-free ATR polymerization of styrene, ${ }^{70}$ while the corresponding $\mathrm{Zn}$ (II) complexes were proved to be active initiators in the ring-opening polymerization (ROP) of D,L-lactide 73, allowing the formation of polylactides 74 with high molecular weight values (Scheme 12). ${ }^{71}$

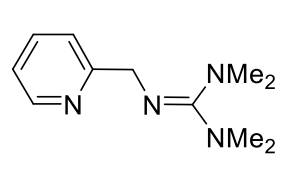

69

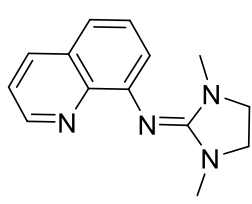

70

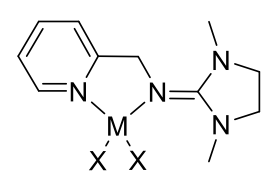

71

$$
\mathrm{M}=\mathrm{Zn}(\mathrm{II}), \mathrm{Co}(\mathrm{II}), \mathrm{Cu}(\mathrm{II})
$$$$
\mathrm{X}=\mathrm{Cl}, \mathrm{CH}_{3} \mathrm{COO}
$$

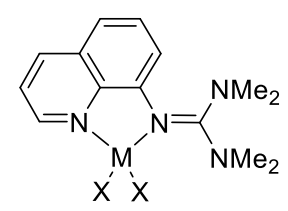

72

$\mathrm{M}=\mathrm{Zn}(\mathrm{II}), \mathrm{Co}(\mathrm{II})$

$\mathrm{X}=\mathrm{Cl}, \mathrm{CH}_{3} \mathrm{COO}$

Figure 6. Hybrid guanidine-pyridine and -quinoline ligands and their complexes with transition metals.

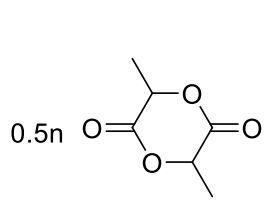

73, D,L-Lactide

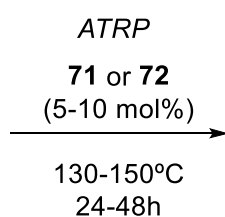

24-48h

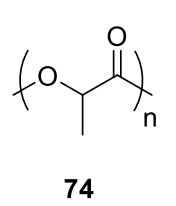

Mw up to $176,000 \mathrm{~g} \mathrm{~mol}^{-1}$

Polydispersities 1.95-2.73)

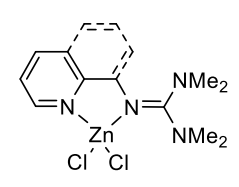

71 (pyridine) 72 (quinoline)

Scheme 12. ATR polymerization of D,L-lactide catalyzed by Zn(II) complexes.

Additionally, hybrid ligands 75-77 that combine a guanidine moiety and an amine group have also been synthetized and their complexes with transition metals synthetized and characterized (Figure 7). For example, the permethylated-amine-guanidine bidentate ligand $\mathbf{7 5}$, based on a 1,3-propanediamine backbone, readily 
reacted with $\mathrm{O}_{2}$ forming a bis( $\mu$-oxo)dicopper(III) complex $\mathbf{7 8}$ capable of promoting an oxidative transformation, such as the hydroxylation of phenolates $\mathbf{7 9}$ to catecholates $\mathbf{8 0}$ in similar manner to tyrosinase (Scheme 13). ${ }^{72}$

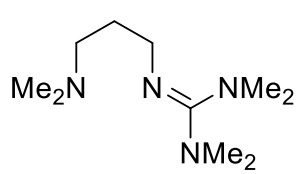

75

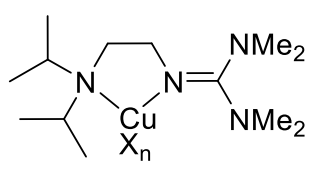

76

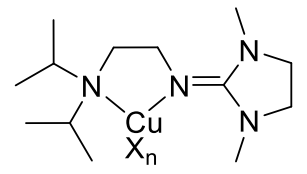

77

$\mathrm{X}=\mathrm{Cl}, \mathrm{Br}, \mathrm{I} ; \mathrm{n}=1,2$

Figure 7. Hybrid guanidine-amine ligands and their complexes with transition metals.

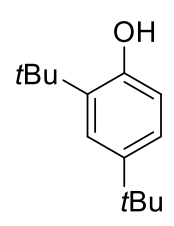

79

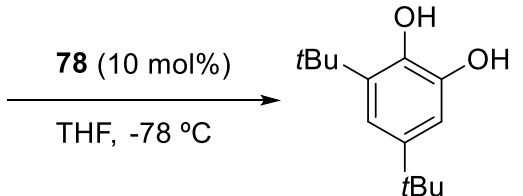

$80,95 \%$

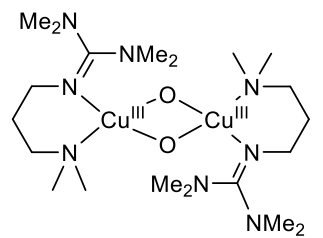

78

Scheme 13. Hydroxylation of phenol derivatives catalyzed by copper complexes.

Later, the same group reported the synthesis of the heterobidentate nitrogen donor ligands $\mathbf{7 6}$ and $\mathbf{7 7}$ depicted in Figure $7,^{73}$ whose catalytic complexes with copper halides were evaluated in atom transfer radical polymerization, showing a high potential activity due to the high polymerization rate, good solubility and an adequate control of radical polymerization.

Chiral metal complexes of guanidine hybrid ligands have been also used as asymmetric catalysts. In this context, Anders group reported the synthesis of chiral $\mathrm{Zn}(\mathrm{II})$ and $\mathrm{Mo}(0)$ guanidine complexes ${ }^{74}$ and investigated the applicability of the neutral $\mathrm{Zn}$ (II) complex $\mathbf{8 1}$ as chiral catalyst in asymmetric Henry reaction between 2-methylpropanol 82 and nitromethane $\mathbf{8 3}$. Thus, the corresponding $\beta$-nitroalcohol 84 was obtained in excellent yield, although with low enantioselectivity (Scheme 14). ${ }^{75}$

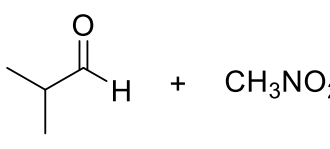

82

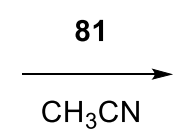

83

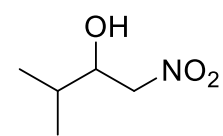

84, $90 \%, 2 \%$ ee

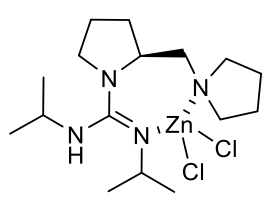

81

Scheme 14. Henry reaction catalyzed by $\mathrm{Zn}(\mathrm{II})$ complexes.

Tamm and coworkers synthesized two quinine-derived guanidine chiral ligands by connecting a quinuclidine core and an imidazolidin-2-imine moiety. This way, the first $N, N$-bidentate ligands bearing a configurationally stable $\mathrm{N}^{*}$-stereogenic center in their uncoordinated form were reported. ${ }^{76}$ These ligands were able to form stable chelate complexes with $\mathrm{Ru}(\mathrm{II}), \mathrm{Pd}(\mathrm{II})$ and $\mathrm{Ni}$ (II), which could show potential utility in asymmetric transition metal catalysis. However, when Ru(II) complexes $\mathbf{8 5}$ and $\mathbf{8 6}$ were tested as catalyst in the enantioselective transfer hydrogenation of acetophenone 87, using 2-propanol as organic hydrogen 
donor, only low enantiomeric excesses of the tertiary alcohol $\mathbf{8 8}$ were obtained, which indicated that the chiral induction of the quinuclidine moiety is not effective (Scheme 15). However, bifunctional chiral guanidine ligands bearing a sulfonamide unit $\mathbf{8 9}$ were found to catalyze efficiently the enantioselective alkynylation of isatins 90 with terminal alkynes 91 in the presence of Cul and 2,4,6-collidine (Scheme 16). ${ }^{77}$

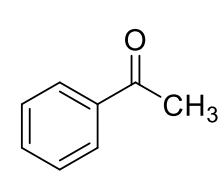

87

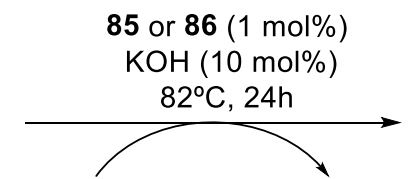

$\mathrm{H}_{3} \mathrm{C} \stackrel{\mathrm{OH}}{\mathrm{CH}_{3}}$

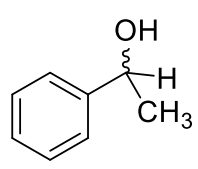

88 82-99\% up to $8 \%$ ee

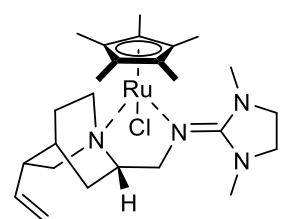

$85\left[\left(\eta^{5}-C_{5} M_{5}\right) R u(D M I Q C I) C l\right]$

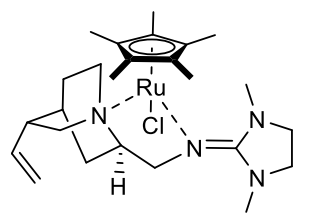

$86\left[\left(\eta^{5}-C_{5} \mathrm{Me}_{5}\right) \mathrm{Ru}(\mathrm{DMIQCD}) \mathrm{Cl}\right]$

Scheme 15. Reduction of acetophenone catalyzed by chiral Ru(II) complexes.

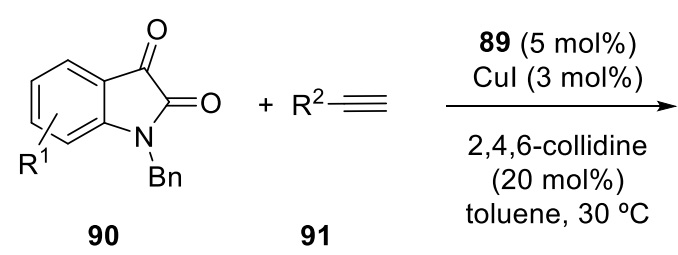

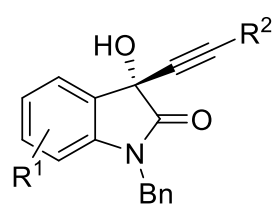

92, $70-99 \%$ $89-97 \%$ ee

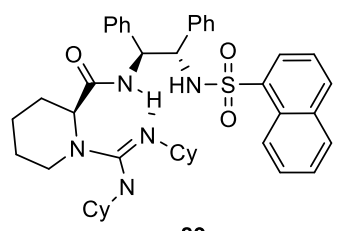

89

Scheme 16. Enantioselective alkynylation of isatins catalyzed by chiral $\mathrm{Cu}(\mathrm{I})$ complexes.

On the other hand, Liu's group has investigated the transition-metal-catalyzed enantioselective $\mathrm{N}-\mathrm{H}$ insertion reaction of $\alpha$-diazocarbonyl compounds, initially studying the insertion of $\mathrm{N}$-sp $\mathrm{s}^{3}$-hybridized $\mathrm{N}-\mathrm{H}$ sources (primary and secondary anilines) using chiral palladium complexes with hybrid guanidines. Thus, various enantioenriched $\alpha$-amino acid derivatives were readily achieved in good yields (24-99\%) and excellent ee values (81-94\% ee). ${ }^{78}$ More recently, they have moved to rhodium catalysis and have used the dirhodium(II) complex with a chiral guanidine 93 for the asymmetric carbene insertion into the $\mathrm{N}-\mathrm{H}$ bond of $\mathrm{N}-\mathrm{sp}^{2}$ hybridized benzophenone imine 94 . Thus, both aromatic and aliphatic substituted $\alpha$-imino esters 96 have been obtained in high yields and enantioselectivities under mild conditions (Scheme 17a). ${ }^{79}$ 


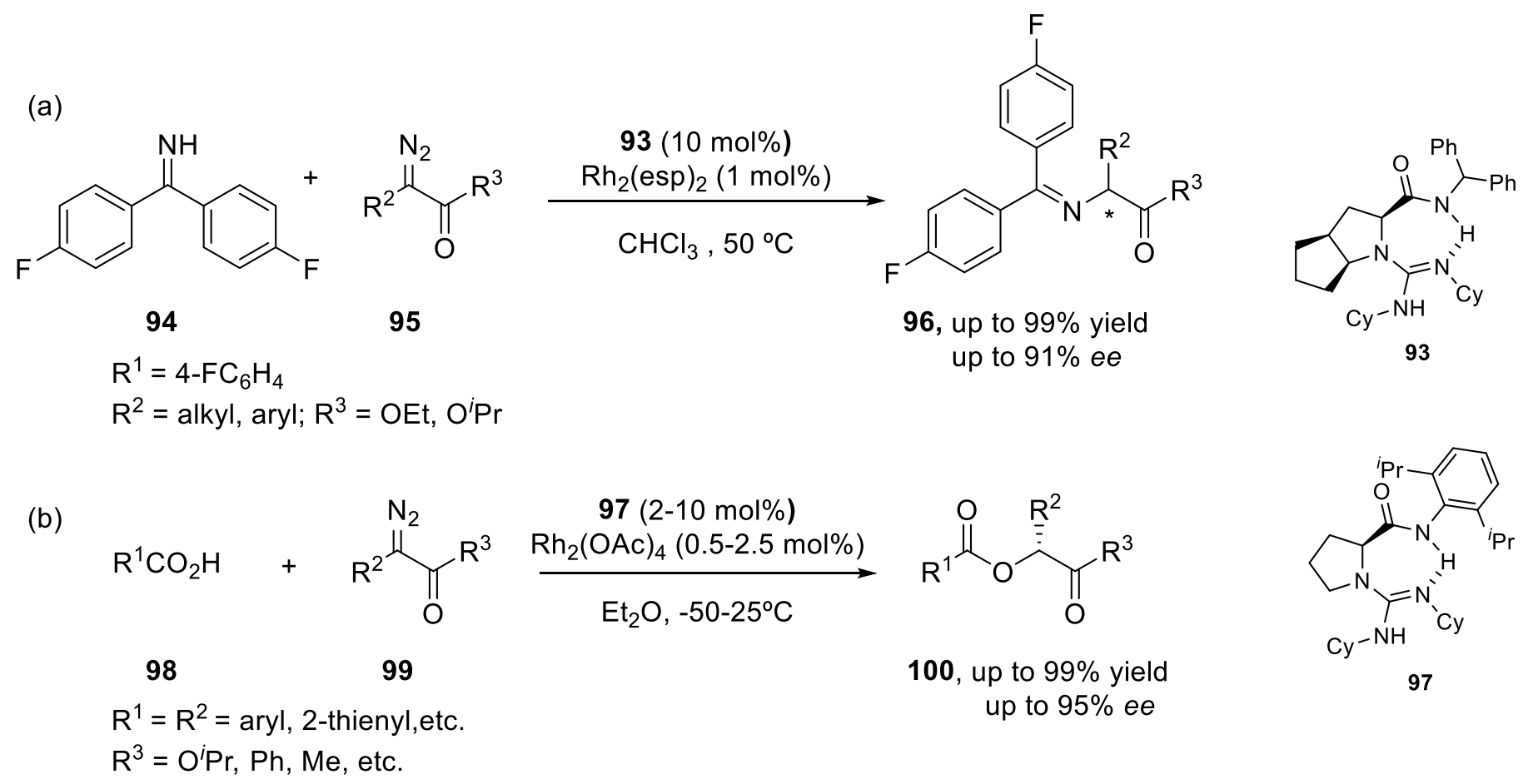

Scheme 17. Enantioselective $\mathrm{N}-\mathrm{H}$ and $\mathrm{O}-\mathrm{H}$ insertion reaction of $\alpha$-diazocarbonyl compounds catalyzed by chiral dirhodium (II) complexes.

The same group has applied this strategy to the enantioselective insertion of $\alpha$-diazocarbonyl compounds into the $\mathrm{O}-\mathrm{H}$ bond of aromatic carboxylic acids 98 for the synthesis of $\alpha$-acyloxy esters and ketones 100 using the related dirhodium(II) complex with guanidine ligand 97 as catalyst (Scheme 17b). ${ }^{80}$

\section{Other Applications}

Besides their role in metal catalyzed reactions, several other applications have been found for guanidine-type ligands in materials and medicinal chemistry areas. For example, the cobalt complexes of guanidine-pyridine hybrid ligands showed a potential application in detector or sensor technology. ${ }^{81}$ The inherent fluorescence of the hybrid ligands was totally quenched when cobalt atom was coordinated, because the change in oxidation state implies a change between diamagnetic and paramagnetic ground state. ${ }^{82}$

Transition-metal complexes of a multidentate Schiff base ligand containing guanidine moiety have been investigated by their potential biological activities. Thus, the $\mathrm{Cu}$ (II) and $\mathrm{Cu}$ (III) complexes showed cytotoxicity against human hepatoma cell line (HepG2) and anti-bacterial and anti-fungal effects in several bacterial and parasitic organisms test (Pseudomonas aeruginosa, Staphylococcus aureus, Candida albicans, and Aspergillus niger). ${ }^{83} \mathrm{Cu}(\mathrm{II})$ complexes with chlorhexidine ${ }^{84}$ have also shown in vitro antibacterial and antifungal activities, against Escherichia coli, Staphylococcus aureus, and Candida albicans. 


\section{Conclusions}

In the last years, great progress has been achieved in synthesis of transition metal complexes with guanidines and their application in different types of catalyzed organic reactions, including polymerization reactions. However, most studies have focused on the preparation and characterization of the complexes, so the need to expand comprehension of structure-catalytic activity relationships remains. Nevertheless, guanidine complexes, known as efficient ligands for ATR polymerization redox reactions (e.g. oxidation, hydroxylation reactions), have begun to play an increasingly important role in carbon-carbon coupling reactions (Heck, Suzuki, cross-dimerization) or click chemistry (1,3-dipolar cycloaddition between azides and alkynes). It is worth mentioning their use in visible light photoredox catalyzed reactions utilizing earth-abundant transition metals as $\mathrm{Co}(I I I)$.

Although some successful results in asymmetric transformations (e.g. oxidation reactions, alkynylation of allylic bromides and isatins, $\mathrm{N}-\mathrm{H}$ and $\mathrm{O}-\mathrm{H}$ insertion reaction of $\alpha$-diazocarbonyl compounds, epoxidation of allylic and homoallylic amines) have been achieved, the potential of chiral guanidine ligands as catalysts for transition metal-catalyzed enantioselective reactions has not been fully addressed. As the introduction of different substituents on the guanidine moiety can modulate the electronic and steric properties of their metal complexes, thus regulating their catalytic activity, we anticipate that new guanidine-based ligands will provide further opportunity for the development of various enantioselective reactions.

\section{Acknowledgements}

Ministerio de Economía y Competitividad (CTQ2016-74881-P) and Gobierno Vasco (IT1045-16) are gratefully acknowledged for their financial support. IB wishes to thank Gobierno Vasco for a grant. Technical and human support provided by Servicios Generales de Investigación SGIker (UPV/EHU, MINECO, GV/EJ, ERDF and ESF) is also acknowledged

\section{References}

1. Ishikawa, T. Chem. Pharm. Bull. 2010, 58, 1555-1564.

https://doi.org/10.1248/cpb.58.1555

2. Ishikawa, T. Ed., Superbases for Organic Synthesis: Guanidines, Amidines, Phosphazenes and Related Organocatalysts; Wiley: Chippenham (England), 2009.

3. Selig, P. Ed., Guanidines as Reagents and Catalysts I. Topics in Heterocyclic Chemistry; Springer: Cham (Switzerland), 2017, Vol. 50.

https://doi.org/10.1007/978-3-319-53013-0

4. Selig, P. Ed., Guanidines as Reagents and Catalysts II. Topics in Heterocyclic Chemistry; Springer: Cham (Switzerland), 2017, Vol. 51.

https://doi.org/10.1007/978-3-319-53013-0

5. Dong, S.; Feng, X.; Liu, X. Chem. Soc. Rev. 2018, 47, 8525-8540.

https://doi.org/10.1039/C7CS00792B

6. Coles, M. P. Dalton Trans. 2006, 985-1001.

https://doi.org/10.1039/b515490a 
7. Stanek, J.; Rösener, T.; Metz, A.; Mannsperger, J.; Hoffmann, A.; Herres-Pawlis, S. Top. Heterocycl. Chem. 2017, 51, 95-164. https://doi.org/10.1007/7081 2015173

8. Cui, X.-Y.; Tan, C.-H.; Leow, D. Org. Biomol. Chem. 2019, 17, 4689-4699. https://doi.org/10.1039/C8OB02240B

9. Martínez Estíbalez, U.; Gómez Sanjuan, A.; García Calvo, O.; Aranzamendi, E.; Lete, E.; Sotomayor, N. Eur. J. Org. Chem. 2011, 3610-3633.

https://doi.org/10.1002/ejoc.201100123

10. Gómez-SanJuan, A.; Sotomayor, N.; Lete, E. Beilstein J. Org. Chem. 2013, 9, 312-322. https://doi.org/10.3762/bjoc.9.36

11. Barbolla, I.; Sotomayor, N.; Lete, E. In Targets in Heterocyclic Chemistry; Attanasi, O. A.; Merino, P.; Spinelli, D. Eds.; Società Chimica Italiana: Roma (Italia), 2019; Vol. 23, pp. 340-362.

12. Carral-Menoyo, A.; Sotomayor, N.; Lete, E. Catal. Sci. Technol. 2020, 10, accepted, https://doi.org/10.1039/D0CY00789G

13. Gómez-SanJuan, A.; Botija, J. M.; Méndez, A.; Sotomayor, N.; Lete, E. Arkivoc 2014 (ii) 44-56. https://doi.org/10.1002/chin.201343252

14. Berlinck, R. G. S.;. Bertonha, A. F.; Takaki, M.; Rodriguez, J. P. G. Nat. Prod. Rep. 2017, 34, 1264-1301. https://doi.org/10.1039/C7NP00037E

15. Li, S.; Xie, H.; Zhang, S.; Lin, Y.; Xu, J.; Cao, J. Synlett 2005, 1885-1888. https://doi.org/10.1055/s-2005-871581

16. Ma, X.; Zhou, Y.; Zhang, J.; Zhu, A.; Jiang, T.; Han, B. Green Chem. 2008, 10, 59-66.

17. Li, S.; Lin, Y.; Cao, J.; Zhang, S. J. Org. Chem. 2008, 72, 4067-4072. https://doi.org/10.1021/jo0626257

18. Yang, H.; Han, X.; Ma, Z.; Wang, R.; Liu, J.; Ji, X. Green Chem. 2010, 12, 441-451. https://doi.org/10.1039/b919175e

19. García-Álvarez, R.; Suárez, F. J.; Díez, J.; Crochet, P.; Cadierno, V.; Antiñolo, A.; Fernández-Galán, R.; Carrillo-Hermosilla, F. Organometallics 2012, 31, 8301-8311.

https://doi.org/10.1021/om3009124

20. Francos, J.; Cadierno, V. Dalton Trans. 2019, 48, 9021-9036. https://doi.org/10.1039/C9DT01289C

21. Ogata, K.; Oka, O.; Toyota, A.; Suzuki, N.; Fukuzawa, S. Synlett, 2008, 2663-2666. https://doi.org/10.1055/s-0028-1083514

22. Eichman, C. C.; Bragdon, J. P.; Stambuli, J. P. Synlett 2011, 1109-1112. https://doi.org/10.1055/s-0030-1259931

23. Chuang, C. J.; Wang, W.; Lee, E.; Ritter, T. J. Am. Chem. Soc. 2011, 133, 1760-1762. https://doi.org/10.1021/ja108396k

24. Cotton, F. A.; Gu, J.; Murillo, C. A.; Timmons, D. J. J. Am. Chem. Soc. 1998, 120, 13280-13281. https://doi.org/10.1021/ja9832313

25. Kovaleva, E. G.; Lipscomb, J. D. Nat. Chem. Biol. 2008, 4, 186-193. https://doi.org/10.1038/nchembio.71

26. Rostovtsev, V. V.; Green, L. G.; Fokin, V. V.; Sharpless, K. B. Angew. Chem. Int. Ed. 2002, 41, $2596-2599$. https://doi.org/10.1002/1521-3773(20020715)41:14<2596::AID-ANIE2596>3.0.CO;2-4

27. Kumar, R.; Ujjval, R.; Thirupathi, N. Eur. J. Inorg. Chem. 2019, 3619-3628. https://doi.org/10.1002/ejic.201900616 
28. Naeimi, H.; Rahmatinejad, S. J. Coord. Chem. 2018, 71, 4210-4227. https://doi.org/10.1080/00958972.2018.1542493

29. Matyjaszewski, K.; Xia, J. Chem. Rev. 2001, 101, 2921-2990. https://doi.org/10.1021/cr940534g

30. Kamigaito, M.; Ando, T.; Sawamoto, M. Chem. Rev., 2001, 101, 3689-3745. https://doi.org/10.1021/cr9901182

31. Pintauer, T.; Matyjaszewski, K. Coord. Chem. Rev. 2005, 249, 1155-1184. https://doi.org/10.1016/i.ccr.2004.11.010

32. Oakley, S. H.; Coles, M. P.; Hitchcock, P. B. Inorg. Chem. 2003, 42, 3154-3156. https://doi.org/10.1021/ic034213b

33. Santos, M. R. E.; Ferreira, S. M.; Mendonça, P. V.; De Bon, F.; Serra, A. C.; Coelho, J. F. J. Polym. Chem. 2019, 10, 4944-4953. https://doi.org/10.1039/C9PY00925F

34. Cui, X.-Y.; Ge, Y.; Tan, S. M.; Jiang, H.; Tan, D.; Lu, Y.; Lee, R.; Tan, C.-H. J. Am. Chem. Soc. 2018, 140, 84488455.

https://doi.org/10.1021/jacs.7b12806

35. Ge, Y.; Cui, X.-Y.; Tan, S. M.; Jiang, H.; Ren, J.; Lee, N.; Lee, R.; Tan, C.-H. Angew. Chem. Int. Ed. 2019, 58, 2382-2386

https://doi.org/10.1002/anie.201813490

36. Polh, S.; Harmjanz, M.; Schneider, J.; Saak, W.; Henkel, G. J. Chem. Soc., Dalton Trans. 2000, 3473-3479. https://doi.org/10.1039/b002554m

37. Peters, A.; Wild, U.; Hübner, O.; Kaifer, E.; Himmel, H.-J. Chem. Eur. J. 2008, 14, 7813-7821. https://doi.org/10.1002/chem.200800244

38. Reinmuth, M.; Wild, U.; Rudolf, D.; Kaifer, E.; Enders, M.; Wadepohl, H.; Himmel, H.-J. Eur. J. Inorg. Chem. 2009, 4795-4808. https://doi.org/10.1002/ejic.200900591

39. Metz, A.; McKeown, P.; Esser, B.; Gohlke, C.; Kröckert, K.; Laurini, L.; Scheckenbach, M.; McCormick, S. N.; Oswald, M.; Hoffmann, A.; Jones, M. D.; Herres-Pawlis, S. Eur. J. Inorg. Chem. 2017, 5557-5570. https://doi.org/10.1002/ejic.201701147

40. Raab, V.; Kipke, J.; Gschwind, R. M.; Sundermeyer, J. Chem. Eur. J. 2002, 8, 1682-1693. https://doi.org/10.1002/1521-3765(20020402)8:7<1682::AID-CHEM1682>3.0.CO;2-R

41. Wild, U.; Hübner, O.; Maronna, A.; Enders, M.; Kaifer, E.; Wadepohl, H.; Himmel, H.-J. Eur. J. Inorg. Chem. 2008, 4440-4447.

https://doi.org/10.1002/ejic.200800677

42. Schön, F.; Biebl, F.; Greb, L.; Leingang, S.; Grimm-Lebsanft, B.; Teubner, M.; Buchenau, S.; Kaifer, E.; Rübhausen, M. A.; Himmel, H.-J. Chem. Eur. J. 2019, 25, 11257-11268.

43. Petrovic, D.; Hill, L. M. R.; Jones, P. G.; Tolman, W. B.; Tamm, M. Dalton Trans. 2008, 887-894. https://doi.org/10.1039/B715590E

44. Petrovic, D.; Glöge, T.; Bannenberg, T.; Hrib, C. G.; Randoll, S.; Jones, P. G.; Tamm, M. Eur. J. Inorg. Chem. 2007, 3472-3475. https://doi.org/10.1002/ejic.200700569

45. Petrovic, D.; Hrib, C. G.; Randoll, S.; Jones, P. G.; Tamm, M. Organometallics 2008, 27, 778-783. https://doi.org/10.1021/om700953u 
46. Bienemann, O.; Froin, A.-K.; Vieira, I. S.; Wortmann, R.; Hoffmann, A.; Herres-Pawlis, S. Z. Anorg. Allg. Chem. 2012, 638, 1683-1690.

https://doi.org/10.1002/zaac.201200092

47. Brar, A. S.; Kaur, S. J. Polym. Sci., Part A: Polym. Chem. 2005, 43, 5906-592.

https://doi.org/10.1002/pola.21076

48. Petrovic, D.; Bannenberg, T.; Randoll, S.; Jones, P. G.; Tamm, M. Dalton Trans. 2007, 2812-2822. https://doi.org/10.1039/b703183a

49. Filimon, S.-A.; Petrovic, D.; Volbeda, J.; Bannenberg, T.; Jones, P. G.; Freiherr von Richthofen, C.-G.; Glaser, T.; Tamm, M. Eur. J. Inorg. Chem. 2014, 5997-6012.

https://doi.org/10.1002/ejic.201402804

50. Panda, T. K.; Petrovic, D.; Bannenberg, T.; Hrib, C. G.; Jones, P. G.; Tamm, M. Inorg. Chim. Acta 2008, 361, 2236-2242.

https://doi.org/10.1016/i.ica.2007.11.027

51. Kawahata, M.; Yamaguchi, K.; Ishikawa, T. Cryst. Growth Des. 2005, 5, 373-377.

https://doi.org/10.1021/cg049864c

52. Roquette, P.; König, C.; Hübner, O.; Wagner, A.; Kaifer, E.; Ender, M.; Himmel, H.-J. Eur. J. Inorg. Chem. 2010, 4770-4782.

https://doi.org/10.1002/ejic.201000315

53. Reinmuth, M.; Neuhaüser, C.; Walter, P.; Enders, M.; Kaifer, E.; Himmel, H.-J. Eur. J. Inorg. Chem. 2011, 8390.

https://doi.org/10.1002/ejic.201000775

54. Wang, C.; Zong, L.; Tan, C.-H. J. Am. Chem. Soc. 2015, 137, 10677-10682.

https://doi.org/10.1021/jacs.5b05792

55. Zong, L.; Wang, C.; Moeljadi, A. M. P.; Ye, X.; Ganguly, R.; Li, Y.; Hirao, H.; Tan, C.-H. Nat. Commun. 2016, 7, $13455-13461$.

https://doi.org/10.1038/ncomms13455

56. Chin, K. F.; Ye, X.; Li, Y.; Lee, R.; Kabylda,A. M.; Leow, D.; Zhang, X.; Ang, E. C. X.; Tan, C.-H. ACS Catal. 2020, 10, 2684-2691.

https://doi.org/10.1021/acscatal.9b04862

57. Hockin, B. M.; Li, C.; Robertson, N.; Zysman-Colman, E. Catal. Sci. Technol. 2019, 9, 889-915. https://doi.org/10.1039/C8CY02336K

58. Pal, A. K.; Li, C.; Hanan, G. S.; Zysman-Colman, E. Angew. Chem. Int. Ed. 2018, 57, 8027-8031. https://doi.org/10.1002/anie.201802532

59. Peters, A.; Kaifer, E.; Himmel, H.-J. Eur. J. Org. Chem. 2008, 5907-5914.

https://doi.org/10.1002/ejoc.200800900

60. Peters, A.; Trumm, C.; Reinmuth, M.; Emeljanenko, D.; Kaifer, E.; Himmel, H.-J. Eur. J. Inorg. Chem. 2009, 3791-3800.

https://doi.org/10.1002/ejic.200900399

61. Emeljanenko, D.; Peters, A.; Wagner, N.; Beck, J.; Kaifer, E.; Himmel, H.-J. Eur. J. Inorg. Chem. 2010, 18391846.

https://doi.org/10.1002/ejic.201000007

62. Schön, F.; Kaifer, E.; Himmel, H.-J. Chem. Eur. J. 2019, 25, 8279-8288.

https://doi.org/10.1002/chem.201900583

63. Vitske, V.; König, C.; Hübner, O.; Kaifer, E.; Himmel, H.-J. Eur. J. Inorg. Chem. 2010, 115-126. 
https://doi.org/10.1002/ejic.200900724

64. Vitske, V.; Roquette, P.; Leingang, S.; Adam, C.; Kaifer, E.; Wadepohl, H.; Himmel, H.-J. Eur. J. Inorg. Chem. 2011, 1593-1604.

https://doi.org/10.1002/ejic.201001202

65. Ziesak, A.; Wesp, T.; Hübner, O.; Kaifer, E.; Wadepohl, H.; Himmel, H.-J. Dalton Trans. 2015, 44, 1911119125.

https://doi.org/10.1039/C5DT03270A

66. Emeljanenko, D.; Peters, A.; Vitske, V.; Kaifer, E.; Himmel, H.-J. Eur. J. Inorg. Chem. 2010, 4783-4789. https://doi.org/10.1002/ejic.201000691

67. Bhattacharjee, S.; Chen, C.; Ahn, W.-S. RSC Adv. 2014, 4, 52500-52525. https://doi.org/10.1039/C4RA11259H

68. Shaabani, A.; Mohammadian, R.; Farhid, H.; Alavijeh, M. K.; Amini, M. M. Catal. Lett. 2019, 149, $1237-1249$. https://doi.org/10.1007/s10562-019-02691-0

69. Börner, J.; Herres-Pawlis, S.; Flörke, U.; Huber, K. Eur. J. Inorg. Chem. 2007, 5645-5651. https://doi.org/10.1002/ejic.200700894

70. Hoffmann, A.; Bienemann, O.; dos Santos-Vieira, I.; Herres-Pawlis, S. Polymers 2014, 6, 995-1007. https://doi.org/10.3390/polym6040995

71. Börner, J.; Flörke, U.; Huber, K.; Döring, A.; Kuckling, D.; Herres-Pawlis, S. Chem. Eur. J. 2009, 15, 23622376.

https://doi.org/10.1002/chem.200802128

72. Herres-Pawlis, S.; Verma, P.; Haase, R.; Kang, P.; Lyons, C. T.; Wasinger, E. C.; Flörke, U.; Henkel, G.; Stack, T. D. P. J. Am. Chem. Soc. 2009, 131, 1154-1169.

https://doi.org/10.1021/ja807809x

73. Bienemann, O.; Haase, R.; Jesser, A.; Beschnitt, T.; Döring, A.; Kuckling, D.; dos Santos-Vieira, I.; Flörke, U.; Herres-Pawlis, S. Eur. J. Inorg. Chem. 2011, 2367-2379.

https://doi.org/10.1002/ejic.201001197

74. Köhn, U.; Günther, W. G.; Görls, H.; Anders, E. Tetrahedron: Asymmetry 2004, 15, 1419-1426. https://doi.org/10.1016/i.tetasy.2004.03.016

75. Köhn, U.; Schulz, M.; Görls, H.; Anders, E. Tetrahedron: Asymmetry 2005, 16, 2125-2131. https://doi.org/10.1016/j.tetasy.2005.04.023

76. Filimon, S.-A.; Hrib, C. G.; Randoll, S.; Neda, I.; Jones, P. G.; Tamm, M. Z. Anorg. Allg. Chem. 2010, 636, 691699.

https://doi.org/10.1002/zaac.200900485

77. Chen, Q.; Tang, Y.; Huang, T.; Liu, X.; Lin, L.; Feng, X. Angew. Chem. Int. Ed. 2016, 55, 5286-5289. https://doi.org/10.1002/anie.201600711

78. Zhu, Y.; Liu, X.; Dong, S.; Zhou, Y.; Li, W.; Lin, L. L.; Feng, X. Angew. Chem. Int. Ed. 2014, 53, 1636-1640. https://doi.org/10.1002/anie.201308501

79. Yang, J.; Ruan, P.; Yang, W.; Feng, X.; Liu, X. Chem. Sci. 2019, 10, 10305-10309. https://doi.org/10.1039/C9SC03354H

80. Tan, F.; Liu, X. H.; Hao, X. Y.; Tang, Y.; Lin, L. L.; Feng, X. M. ACS Catal. 2016, 6, 6930-6934. https://doi.org/10.1021/acscatal.6b02184

81. Hoffmann, A.; Börner, J.; Flörke, U.; Herres-Pawlis, S. Inorg. Chim. Acta 2009, 362, 1185-1193. https://doi.org/10.1016/j.ica.2008.06.002

82. De Santis, G.; Fabbrizzi, L.; Licchelli, M.; Mangano, C.; Sacchi, D. Inorg. Chem. 1995, 34, 3581-3591. 
https://doi.org/10.1021/ic00118a003

83. El-Razek, S. E. A.; El-Gamasy, S. M.; Hassan, M.; Abdel-Aziz, M. S.; Nasr, S. M. J. Mol. Struct. 2020, 1203, 127381. https://doi.org/10.1016/j.molstruc.2019.127381

84. Badea, M.; Olar, R.; Ilis, M.; Georgescu, R.; Calinescu, M. J. Therm. Anal. Calorim. 2013, 111, 1763-1770. https://doi.org/10.1007/s10973-012-2316-4

\section{Authors' Biographies}

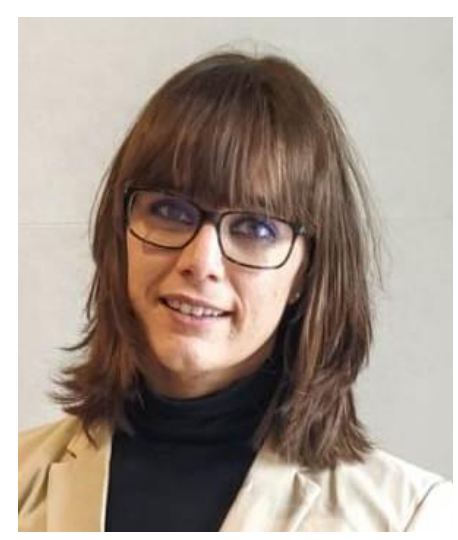

Iratxe Barbolla recently obtained her Ph.D. from the University of the Basque Country (2020) working on the development of carbopalladation initiated cascade reactions for the synthesis of heterocyclic systems, under the supervision of Prof. Lete and Sotomayor. She has also started studying the application of guanidine-amine ligands on metal catalyzed reactions. During her Ph.D. work, in 2017, she did a three-month stay in the group of Prof. Laura Anderson at the University of Illinois at Chicago.

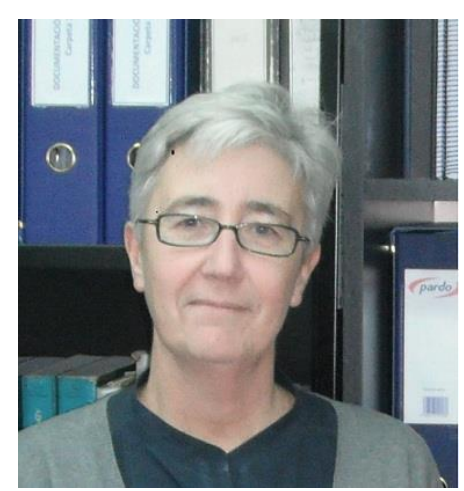

Nuria Sotomayor obtained her Ph.D. (1993) at the University of the Basque Country. After postdoctoral research at the University of Waterloo (Canada) with Prof. Victor Snieckus (1994-1995), she returned to the Organic Chemistry Dept. of the University of the Basque Country in Bilbao (1995), where she was promoted to Full Professor in 2010. Her current research interest is focused on the development of methodology based on organometallic chemistry and asymmetric catalysis, applied to the synthesis of heterocyclic systems, potentially active compounds, natural products or drugs. 


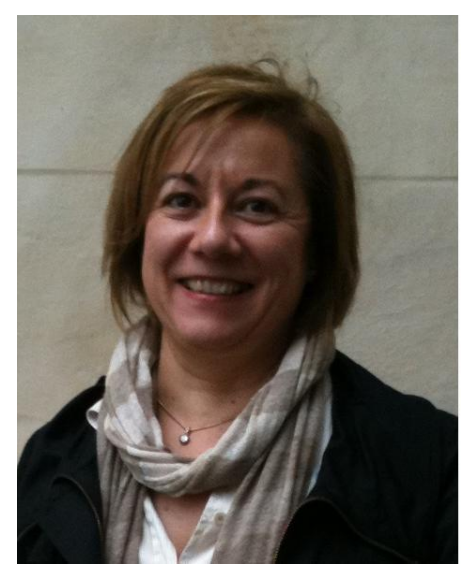

Esther Lete studied chemistry at the University of the Basque Country (UPV/EHU), where she received her PhD in 1982. After a stay in University College London studying the chemistry and synthetic applications of carbanions, she took up a lectureship in organic chemistry at the University of the Basque Country and was promoted to Full Professor in 1997. Her research interests include organometallic chemistry and asymmetric catalysis with a focus on developing synthetic methodologies based on transition metal-catalyzed $\mathrm{C}-\mathrm{H}$ activation, alkenylation, arylation or acylation reactions for the synthesis and functionalization of heterocyclic systems. 